\title{
Recent Advances in substrate utilization for fermentative hydrogen Production
}

\author{
Pankaj K. Rai* \\ Department of Biotechnology and Bioinformatics Centre, Barkatullah University, Bhopal-462026, M.P., India.
}

\section{ARTICLE INFO}

Article history:

Received on: 17/06/2016

Revised on: 14/07/2016

Accepted on: 29/07/2016

Available online: 05/11/2016

Key words:

Biohydrogen; waste water;

food waste; algal biomass;

cellulosic waste.

\begin{abstract}
In many ways, hydrogen is considered to be the ideal fuel for the future. Biohydrogen production processes are considered as the most environmentally friendly in comparison to others. Biological hydrogen production processes (both dark- and photo- fermentation) are considered most favorable. Due to their high conversion efficiency and versatility of the substrate they can utilize. The use of waste materials as substrate not only generates energy but it also helps in the bioremediation. The potential utilization of waste material for $\mathrm{H}_{2}$ production is being investigated extensively. The present review article aims to summarize the recently used substrates for fermentative biohydrogen production.
\end{abstract}

\section{INTRODUCTION}

Today, the world is facing two major issues; global climate change due to combustion of fossil fuels and energy crisis due to exhaustion of existing fossil fuels. Almost every country is concerned about this grave situation, and spending a lot of money to address the two issues. Fossil fuels are limited, and are on the verge of their depletion. The depletion of fossil fuels raises the question to find the alternative energy sources, and ranks as one of the most challenging problems of mankind. $\mathrm{H}_{2}$ is considered as a clean energy with no $\mathrm{CO}_{2}$ emissions having high energy yield of $122 \mathrm{KJ} / \mathrm{g}, 2.75$ times over the hydrocarbon fuels [1-2]. $\mathrm{H}_{2}$ seems a promising candidate to replace the fossil fuels, and is produced biologically via biophotolysis, darkfermentation and photo- fermentation. Hydrogen produced biologically is known as biohydrogen. The advances in biohydrogen production technologies based on organic wastewater conversions could solve the issues pertaining to food security, climate change, energy security and clean development in the near future [3]. Biological methods of $\mathrm{H}_{2}$ production

\footnotetext{
* Corresponding Author

Pankaj Kumar Rai, Department of Biotechnology Barkatullah University, Bhopal-462026, M.P., India. Tel: (O): 91-07552-491849; (B):91-9009938521, Email: pankajraibhu@gmail.com
}

are preferred over the chemical ones, as they are less energy intensive, and utilize organic wastes as the feedstock. Biohydrogen could be produced commercially at large scale by using efficient $\mathrm{H}_{2}$ producing microorganisms from the readily available, renewable substrates. The cost of the substrate plays a major role in the economics of biohydrogen production. Therefore, scientists working in the area of biohydrogen have more concern for the cost of substrate.

Cheaper and abundant feedstock can make the biohydrogen process economically viable. The efficient utilization of organic wastes from industries and agriculture as substrate for biohydrogen production not only supports green energy generation but also helps in bioremediation [4]. Pure sugars are also used as substrate for biohydrogen production, but they are costly. Wastes like agricultural residues [5], food wastes [6] and effluents from industrial processes such as dairy wastewater [7] olive processing [8] and cheese production [9] can be used as substrate for biohydrogen production.

Utilization of these wastes as substrate for biohydrogen proves to have dual economic benefit of energy production and savings in the cost of waste disposal. The present review is an attempt to narrate recent advances in substrate utilization for biohydrogen production, and specific attention has been paid to the recently used substrates for sustained $\mathrm{H}_{2}$ production on a costeffective basis. 


\section{PROCESSES FOR BIOHYDROGEN PRODUCTION}

Biologically hydrogen can be produced by direct biophotolysis, indirect biophotolysis, dark- fermentation and photo- fermentation [3]. Direct- biophotolysis is carried out in the presence of sunlight by green algae using readily available water as substrate.

In direct biophotolysis light energy absorbed by PSII and PSI helps to transport electrons from water to ferredoxin and reduced ferredoxin acts as an electron donor to a hydrogenase enzyme, which reversibly catalyzes the reduction of proton $\left(\mathrm{H}^{+}\right)$to molecular hydrogen [10]. The main disadvantage of this process is low light conversion efficiencies and $\mathrm{O}_{2}$ labile hydrogen production system. Indirect biophotolysis is carried out by filamentous cyanobacteria both nitrogen fixing and non- nitrogen fixing.

In cyanobacteria photosynthesis and nitrogen fixation reactions are spatially separated from each other. Major drawbacks of this process are presence of uptake hydrogenase enzyme and low $\mathrm{H}_{2}$ production rates. Dark- fermentation carried out under anaerobic conditions seems to be more favourable, since hydrogen is yielded at a high rate with various organic substrates and waste waters enriched with carbohydrates [11]. Currently, darkfermentation technologies are under development at laboratory scale to produce biohydrogen from organic wastes. During the dark- fermentation simple sugars are converted into $\mathrm{H}_{2}$, VFAs and alcohols which are organic pollutant and energy carriers. In photofermentation process, under anaerobic conditions, photosynthetic bacteria use light as energy source and assimilate small organic acids to produce biomass, $\mathrm{H}_{2}$ and $\mathrm{CO}_{2}$. Purple non- sulfur bacteria (PNS) are considered as promising candidates for photofermentative $\mathrm{H}_{2}$ production due to their ability of high substrate conversion efficiencies, being able to utilize wide range of the solar spectrum and flexibility in utilization of wide variety of organic wastes [1]. The use of dark- fermentation along with photo- fermentation as second step not only allows the effective utilization of the substrate but also improve the overall $\mathrm{H}_{2}$ yield [12].

\section{SUBSTRATES FOR BIOHYDROGEN PRODUCTION}

The use of synthetic media for microbial growth and maintenance is ideal; however, their use for commercial scale is not suitable because of the cost involved. Hence, for the commercial production of biohydrogen, utilization of various domestic, agricultural and industrial wastes rich in organic matter not only lowers the production costs, it also helps in removal of these wastes from the environment [12].

However, there is a need of pre-treatment of these waste materials before their use for biohydrogen production. The pre-treatment of the wastes potentially enhances the biodegradability of the wastes by microorganisms thus increasing the efficiency/yield of biohydrogen production. The various types of wastes used for biohydrogen production are:

\subsection{Industrial waste}

Considerable research is going on for the utilization of industry waste as substrate for biohydrogen production (Table 1). The food industry produces wastes/wastewaters highly concentrated in carbohydrates e.g. sugars, starch and cellulose. The high organic loading and other growth factors that support microbial growth makes such wastes/wastewaters the potential and important feedstock for biohydrogen production. Before using them as substrate for biohydrogen production, such wastewaters need to be pre-treated for $\mathrm{pH}$ and nutrient balance. Many wastes or wastewaters like olive mill effluent consist of ethanol, acetate, butyrate, and propionate, and are reported to be best suited for photo- biological $\mathrm{H}_{2}$ production. Kim et. al., [13] investigated the potential of using the industrial effluents of Makkoli (raw rice wine), Tofu (soybean curd) wastewaters and sewage sludge as substrates for $\mathrm{H}_{2}$ production in combination with darkfermentation by $C$. butyricum NCIB 9576 and photo- fermentation of the spent media by purple non-sulfur photosynthetic bacteria. From the Makkoli wastewater, approximately $1 \mathrm{~L} \mathrm{H}_{2} / \mathrm{L}$ wastewater was produced during the dark- fermentation. About $0.44 \mathrm{~L} \mathrm{H}_{2} / \mathrm{L}$ broth /day was produced during photo fermentation. Tofu wastewater, generates about $0.9 \mathrm{~L} \mathrm{H}_{2} / \mathrm{L}$ wastewater during darkand $0.2 \mathrm{~L} \mathrm{H}_{2} / \mathrm{L}$ broth /day during photo- fermentation. Sewage sludge was pre-treated for $1 \mathrm{~h}$ at $150{ }^{\circ} \mathrm{C}$ under $10 \mathrm{~atm}$ after alkali treatment before it could be used as substrate. It continuously produced 0.17-0.28 $1 \mathrm{~L} \mathrm{H}_{2} / \mathrm{L}$ broth/day during photo- fermentation. The data suggested that organic rich industrial effluents of Makkoli and Tofu wastewater and sewage sludge were the promising substrates for $\mathrm{H}_{2}$ production and for the treatment of organic waste and wastewater. Eroglu et. al. [8] used Olive mill wastewater (OMW) containing carbon, hydrogen, and nitrogen in suspended solids as sole substrate for the biohydrogen production by Rhodobacter sphaeroides O.U.001 in glass columnphotobioreactors. OMW was diluted in the range of $20 \%(\mathrm{v} / \mathrm{v})$ and $1 \%(\mathrm{v} / \mathrm{v})$ OMW containing media.

Maximum hydrogen production potential (HPP) was found at $2 \%$ OMW. During the fermentation process, chemical oxygen demand (COD) of the diluted wastewater decreased from 1100 to $720 \mathrm{mg} / \mathrm{L}$; biochemical oxygen demand (BOD) decreased from 475 to $200 \mathrm{mg} / \mathrm{L}$. The results concluded OMW to be a very promising substrate for biohydrogen production. Seifert et. al. [7] used dairy wastewater as substrate for hydrogen production by $R$. sphaeroides O.U. 001. Concentration of the waste varied from 5 to $40 \%, \mathrm{v} / \mathrm{v}$, keeping the inoculum $0.36 \mathrm{~g}$ dry wt/L under illumination of $9 \mathrm{klx}$. The highest volumetric hydrogen was obtained at concentration of $40 \mathrm{v} / \mathrm{v} \%$, but the maximal substrate yield was at lower concentrations of the waste $(5-10 \mathrm{v} / \mathrm{v} \%)$. Cappelletti et. al. [14] used cassava processing wastewater for biohydrogen production by Clostridium acetobutylicum ATCC 824.

They studied the effect of initial substrate concentration on COD consumption, $\mathrm{pH}$, and $\mathrm{H}_{2}$ production. Higher substrate concentrations ( 30.0 and 15.0 COD/L) led to lower $\mathrm{H}_{2}$ yield and substrate conversion efficiency. 
Table 1: Industrial waste/wastewaters used as substrate for biohydrogen production.

\begin{tabular}{|c|c|c|c|c|}
\hline S. No. & Waste/waste water & Inoculum & Highest $\mathrm{H}_{2}$ yield & Reference \\
\hline 1. & Cheese whey & Clostridium saccharoperbutylacetonicum & $0.028 \mathrm{~L} / \mathrm{h}$ & [60] \\
\hline 2. & Cheese processing waste water & Sewage sludge & $2.3 \mathrm{mmol} / \mathrm{g} \mathrm{COD}$ & [61] \\
\hline 3. & Cheese whey waste water & Anaerobic digester sludge & $22 \mathrm{mmol} \mathrm{H}_{2} / \mathrm{g} \mathrm{COD}$ & [62] \\
\hline 4. & Cereal waste water & Dewatered sewage sludge & $0.79 \mathrm{~mol} \mathrm{H}_{2} / \mathrm{mol}$ glucose & [63] \\
\hline 5. & Cheese whey & Anaerobic granular sludge & $2.8 \mathrm{~mol} \mathrm{H}_{2} / \mathrm{mol}$ hexose & {$[64]$} \\
\hline 6. & Cheese whey & E. aerogenes & $2.04 \mathrm{~mol} \mathrm{H}_{2} / \mathrm{mol}$ lactose & [9] \\
\hline 7. & Cassava waste water & Pond sludge & $1.91 \mathrm{~mol} \mathrm{H}_{2} / \mathrm{mol}$ glucose & {$[65]$} \\
\hline 8. & Olive mill waste water & Rhodobacter sphaeroides O.U.001 & $13.9 \mathrm{~L} \mathrm{H}_{2} / \mathrm{L} \mathrm{OMW}$ & [8] \\
\hline 9. & Cassava processing waste water & Clostridium acetobutylicum ATCC 824 & $2.41 \mathrm{~mol} \mathrm{H}_{2} / \mathrm{mol}$ glucose & [14] \\
\hline 10. & Dairy waste water & Rhodobacter sphaeroides O.U.001 & 3.6 $\mathrm{L} \mathrm{H}_{2} / \mathrm{L}$ dairy wastewater & [7] \\
\hline
\end{tabular}

Whereas, low COD concentrations increased $\mathrm{H}_{2}$ yield up to $2.41 \mathrm{~mol} \mathrm{H}_{2} / \mathrm{mol}$ glucose, with efficiency of $60 \%(\mathrm{~mol} / \mathrm{mol})$, respectively. The results demonstrated the successful utilization of cassava processing wastewater for $\mathrm{H}_{2}$ production by $C$. acetobutylicum. Cheese whey, the by-product of cheese industry has high organic load. The presence of high amount of lactose and minerals in whey make it a potential substrate for biohydrogen production [15-17]. Rai et. al. [9] reported biohydrogen production from cheese whey in a two- step dark- and photofermentation process by free and immobilized bacterial cells. The cumulative $\mathrm{H}_{2}$ yield for free and immobilized bacterial cells during two- step process was 3.40 and $5.88 \mathrm{~mol} / \mathrm{mol}$ lactose, respectively. The data suggested that the use of cheese whey as substrate with immobilized bacterial cells has good potential for biohydrogen production and effective removal of organic load from the wastewater. Further, Rai et. al. [17] optimized the concentration of essential trace elements required for growth/metabolism of most microorganisms to enhance the hydrogen yield during photofermentation step. Spent medium generated after darkfermentation of cheese whey wastewater by Enterobacter aerogenes MTCC 2822, was subjected to photo- fermentation through enrichment by $\mathrm{Ni}^{2+}(0-8 \mu \mathrm{mol} / \mathrm{L}), \mathrm{Fe}^{2+}(0-100 \mu \mathrm{mol} / \mathrm{L})$ or $\mathrm{Mg}^{2+}$ (0-15 mmol/L) by Rhodopseudomonas BHU 01 strain. The results clearly indicated $4 \mu \mathrm{mol} \mathrm{Ni}{ }^{2+} / \mathrm{L} \mathrm{Fe}^{2+}(60 \mu \mathrm{mol} / \mathrm{L})$ resulted in maximum cumulative $\mathrm{H}_{2}$ production and yield. Nevertheless, even $6 \mathrm{mmol}$ of $\mathrm{Mg}^{2+}$ did not significantly affect $\mathrm{H}_{2}$ production $(110 \mathrm{ml})$ or yield $(44 \mathrm{mmol})$. The observations suggested the role of $\mathrm{Fe}^{2+}$ and $\mathrm{Ni}^{2+}$ in regulation of nitrogenase and hydrogenase enzyme, while $\mathrm{Mg}^{2+}$ mainly in the biosynthesis of photopigment bacteriochlorophyll (Bchl). Xiao et. al. [18] reported bio-hydrogen production from protein wastewater by altering protein structure and amino acids acidification type via $\mathrm{pH}$ control. The hydrogen production reached $205.2 \mathrm{~mL} / \mathrm{g}$ protein when protein wastewater was pre-treated at $\mathrm{pH} 12$ and then fermented at $\mathrm{pH} 10$. The studies showed that the pre-treatment significantly enhanced protein biohydrolysis during the subsequent fermentation stage as it caused the unfolding of protein, damaged the protein hydrogen bonding networks, and destroyed the disulfide bridges, which increased the susceptibility of protein to protease.

\subsection{Food waste}

Food waste rich in sugars is an attractive substrate for biohydrogen production (Table 2). The presence of moisture
(72-85.2\%), high organic load (COD: 19.3-346 g/L; carbohydrate: 25.5-143 g/L) and high carbon to nitrogen $(\mathrm{C} / \mathrm{N})$ ratio $(9-21)$ make food waste a suitable substrate for biohydrogen production [1921]. In addition, other characteristics such as volatile solid composition, particle size and biodegradability are also important to achieve high hydrogen yield [22]. Food composition varies from source to source thus influencing the process parameters drastically.

High concentration of proteins, fats and lipids in the food waste adversely affects the hydrogen production as these are not easily degraded by the microorganisms employed for hydrogen production. The presence of lipids and fats in an anaerobic fermenter resulted in flotation, clogging and mass transfer problems. Use of high temperature is suggested to prevent the clogging problem during anaerobic degradation of lipids [23]. But increasing the temperature beyond the optimum range of the fermentation process decreases the hydrogen yield. Pre-treatment of food waste is regarded as the important parameter in influencing biohydrogen production and yield [24]. Pre- treatment of food waste is done to eliminate the indigenous microflora present in the food waste. The indigenous mixed microflora may contain hydrogen producing or hydrogen consuming bacteria, methane producing bacteria and acid producing bacteria. Therefore, pretreatment of the indigenous microorganisms present in food waste by heat, chemical or $\mathrm{pH}$ shock to promote growth of hydrogenproducing bacteria and elimination of hydrogen- consuming bacteria [25]. Many workers reported the dominance of hydrogen producing bacteria such as Clostridium sp., and Caloramator australicus after heat treatment for biohydrogen production study using food waste as the substrate [26-28]. In case, no pretreatment is applied to the food waste microflora before its use as substrate the number of methane- and acid-producing bacteria will increase and hydrogen-producing bacteria remain encapsulated by the spores. The heat pre- treatment is chosen by most because of its simplicity in application, short time and low cost. On the other hand, pre- treatment by chemicals (alkali, acid or chemical shock) takes long time, and is costly [25, 29].

A combination of pre- treatments is also reported by Elbeshbishy et. al. [30]. Four individual pre-treatment methods: ultrasonication, heat, acid, and base and three combined pretreatment methods comprising ultrasonication with heat (UH), ultrasonication with acid (UA), and ultrasonication with base (UB) were applied on the food waste. 
Table 2: Food waste used as substrate for biohydrogen production.

\begin{tabular}{|c|c|c|c|c|}
\hline S. No. & Food waste & Inoculum & Highest $\mathrm{H}_{2}$ yield & Reference \\
\hline 1. & Food waste & Heat shock treated anaerobic sludge & $310 \mathrm{~mL} \mathrm{H}_{2} / \mathrm{g} \mathrm{VS}_{\text {added }}$ & {$[66]$} \\
\hline 2. & Food waste & Thermophilic acidogenic culture & $46.3 \mathrm{~mL} \mathrm{H}_{2} / \mathrm{g} \mathrm{VS}_{\text {added }}$ & [31] \\
\hline 3. & Rice slurry & Anaerobic digested sludge & $346 \mathrm{~mL} \mathrm{H}_{2} / \mathrm{g}$ carbohydrate & [6] \\
\hline 4. & Pine apple waste & Municipal sewage sludge & $5920 \mathrm{mmol} \mathrm{H}_{2} / \mathrm{g} \mathrm{COD}$ & [67] \\
\hline 5 . & Kitchen waste & Digested slurry & $72 \mathrm{~mL} \mathrm{H}_{2} / \mathrm{g} \mathrm{VS}_{\text {added }}$ & [19] \\
\hline 6. & Wasted bread & Rice rhizosphere & $1.3 \mathrm{~mol} \mathrm{H}_{2} / \mathrm{mol}$ hexose & [68] \\
\hline 7. & Vegetable kitchen waste & Kitchen waste compost & $38 \mathrm{~mL} \mathrm{H}_{2} / \mathrm{g} \mathrm{COD}$ & [23] \\
\hline 8. & Fully ripened fruits & Sewage sludge & $2.2 \mathrm{~mol} \mathrm{H}_{2} / \mathrm{mol}$ glucose & [20] \\
\hline 9. & Kitchen waste & Mixed sludge & $96 \mathrm{~mL} \mathrm{H}_{2} / \mathrm{g} \mathrm{VSS}$ & [69] \\
\hline 10. & Food waste (rice, fish and vegetable) & Palm oil mill effluent sludge & $79 \mathrm{mmol} \mathrm{H}_{2} / \mathrm{L} \mathrm{media/day}$ & [28] \\
\hline
\end{tabular}

There is a lot of variation in characteristics of food waste being used for biohydrogen production as the type of waste generated in different countries is different. Zhang et. al. [22] collect food waste in the city of San Francisco, California, USA and characterized its potential as the feedstock for anaerobic digestion processes. They measured the daily and weekly variations of food waste composition over a two-month period due to daily variation in the food waste composition. Water is generally added to homogenize/dilute the food waste before it is being used [31-32]. The dilution of food waste facilitates the use of optimum concentration of sugars (COD) for fermentative hydrogen production. Hwang et. al. [20] used different ripened fruits (apple, pear, and grape) as feedstock for hydrogen production in two-stage fermentation. Ripened apple was the most promising substrate for cumulative $\mathrm{H}_{2}$ production with a maximum $\mathrm{H}_{2}$ yield (2.2 $\left.\mathrm{mol} \mathrm{H}_{2} \mathrm{~mol} / \mathrm{glucose}\right)$ in the first stage, and additional cumulative biohydrogen $\left(3337.4 \mathrm{~mL} \mathrm{H}_{2} / \mathrm{L}\right.$ culture) in the second stage. The study demonstrated that ripened fruits could be used as substrates for biohydrogen fermentation. A novel process that produces $\mathrm{H}_{2}$ without inoculum addition was reported by Kim et. al. [24]. Food waste utilized as substrate acts not only as a substrate but also as a source of $\mathrm{H}_{2}$-producing microflora in case heat $\left(90{ }^{\circ} \mathrm{C}\right.$ for $20 \mathrm{~min}$ ), acid ( $\mathrm{pH} 1.0$ for $1 \mathrm{~d}$ ), or alkali ( $\mathrm{pH} 13.0$ for $1 \mathrm{~d}$ ) treatment was applied. The effect of initial $\mathrm{pH}$ on hydrogen production from food waste was investigated by Kim et. al. [33]. At initial pH 8.0 $\mathrm{H}_{2}$ yield 1.3-1.9 $\mathrm{mol} \mathrm{H}_{2} / \mathrm{mol} \mathrm{hexose}_{\text {added }}$ was achieved which corresponded to $8.13 \%$ of the total energy content in the substrate. Vegetable based market waste was evaluated as the substrate for hydrogen production using selectively enriched acidogenic mixed consortia under acidophilic microenvironment by Venkata Mohan et. al. [34]. Different substrate/organic loading conditions in concurrence with two types of feed compositions (with and without pulp) were investigated. $\mathrm{H}_{2}$ production was found to be dependent on the substrate concentration and composition, and it was high in experiments performed without pulp. Results indicated the feasibility of vegetable waste for $\mathrm{H}_{2}$ production.A pilot-scale anaerobic sequencing batch reactor (ASBR) treating food waste was used for $\mathrm{H}_{2}$-production by $\mathrm{Kim}$ et. al. [35]. To vary the carbon/nitrogen $(\mathrm{C} / \mathrm{N})$ ratio from 10 to 30 , the composition of the food waste was changed. It was found that when the $\mathrm{C} / \mathrm{N}$ ratio was lower than 20 ,

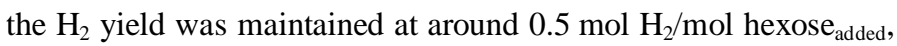
but it gradually dropped at higher $\mathrm{C} / \mathrm{N}$ ratios mainly due to the production of lactate, propionate, and valerate. Alkaline shock $(\mathrm{pH}$ 12.5 for 1 day) was given to recover the yield, and it was so effective that the $\mathrm{H}_{2}$ yield significantly increased to over $0.9 \mathrm{~mol}$

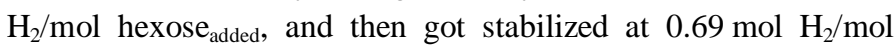
hexose $_{\text {added. }}$. Canteen based composite food waste was used as substrate for biohydrogen production in an anaerobic sequencing batch reactor (AnSBR) at $\mathrm{pH} 6$ with five variable organic loading conditions (OLR1, 0.854; OLR2, 1.69; OLR3, 3.38; OLR4, 6.54 and OLR5, $9.85 \mathrm{~kg} \mathrm{COD} / \mathrm{m}^{3} /$ day) to find the influence of carbohydrates and proteins concentration on fermentative hydrogen production [36]. The data suggested that $\mathrm{H}_{2}$ production depends on the substrate load. OLR4 supported maximum $\mathrm{H}_{2}$ production (69.95 $\mathrm{mmol})$, while higher substrate degradation (3.99 $\mathrm{kg} \mathrm{COD} / \mathrm{m}^{3} /$ day) was observed with OLR5.

\subsection{Lignocellulosic biomass}

Lignocellulosic biomass is considered as the most abundant raw material found in nature ranging from hardwood, soft wood, grasses, agricultural and forestry residues as well as secondary biofuels wastes. The annual worldwide yield of lignocellulosic biomass residue is estimated to exceed 220 billion tons [37]. Although, being an abundant and almost zero cost feedstock, agricultural and forestry residues do not contain easily fermentable free sugars, but complex carbohydrate polymers, i.e., cellulose and hemicelluloses, which are tightly bonded to lignin [38]. Thus utilization of these as a substrate for biohydrogen production is not an easy task due to the presence of non biodegradable lignin coating. Therefore, prior to use biomass as a substrate, pre-treatments such as physical, chemical and biological or a combination of these seem necessary (Table 3). The pretreatment of the biomass decreases the crystallinity and increase the surface area to improve the consumption by the microorganisms and yield simple sugars for fermentation. Cellulose rich corncobs are abundant in nature and its composition makes it a potential substrate for $\mathrm{H}_{2}$ production. Hydrogen production from acid and enzyme pre-treated corncob by integrating dark-fermentation with photo-fermentation was investigated by Yang et. al. [39]. In the first step, dark fermenting microflora obtained from dairy manure produced maximum biohydrogen yield and rate $120.3 \pm 5.2 \mathrm{~mL} \mathrm{H}_{2} / \mathrm{g}$ corncob and $150 \mathrm{~mL}$ $\mathrm{H}_{2} / \mathrm{L}$ h, respectively. In the second step, Rhodobacter sphaeroides isolated from sedimentation tank of sewage plant yielded $713.6 \pm$ $44.1 \mathrm{~mL} \mathrm{H}_{2} / \mathrm{g}$-COD hydrogen. 
Table 3: Lignocellulosic waste used as substrate for biohydrogen production

\begin{tabular}{|c|c|c|c|c|}
\hline S. No. & Biomass & Inoculum & Highest $\mathrm{H}_{2}$ yield & Reference \\
\hline 1. & Sugarcane bagasse & C. butyricum & $1.73 \mathrm{~mol} \mathrm{H}_{2} / \mathrm{mol}$ total sugar & [70] \\
\hline 2. & Sweet sorghum bagasse & C. saccharolyticus & $73.6 \mathrm{~mL} \mathrm{H}_{2} / \mathrm{mmol}$ hexose sugars & [71] \\
\hline 3. & Cornstalk & Heat pre-treated anaerobic sludge & $126.22 \mathrm{~mL} \mathrm{H}_{2} / \mathrm{g}$ dry biomass & [72] \\
\hline 4. & Wheat Straw & Anaerobic mixed culture & $22.4 \mathrm{~mL} \mathrm{H}_{2} / \mathrm{mmol}$ glucose & [73] \\
\hline 5. & Lawn grass & Enriched mixed culture dominated by $C$. pasteurianum & $72.21 \mathrm{~mL} \mathrm{H}_{2} / \mathrm{g}$ dry biomass & [74] \\
\hline 6. & Soybean straw & Enriched mixed culture dominated by $C$. butyricum & $60.2 \mathrm{~mL} \mathrm{H}_{2} / \mathrm{g}$ dry biomass & [75] \\
\hline 7. & Water hyacinth and beverage wastewater & Pig slurry & $13.65 \mathrm{~mL} \mathrm{H}_{2} / \mathrm{g}$ dry feedstock & [76] \\
\hline 8. & Corn stalk & T. thermosaccharolyticum $\mathrm{W} 16$ & $89.3 \mathrm{~mL} \mathrm{H}_{2} / \mathrm{g}$ dry biomass & [77] \\
\hline 9. & Sugarcane bagasse & E. aerogenes & $1000 \mathrm{ml} / \mathrm{L}$ hydrolysate & [44] \\
\hline 10. & Corn stalk & C. butyricum & $92.9 \mathrm{~mL} \mathrm{H}_{2} / \mathrm{g}$ dry biomass & [78] \\
\hline
\end{tabular}

This study successfully demonstrated the feasibility of converting corncob into high-yield hydrogen. Cassava is a low cost starch rich crop used for production of starch. Cassava pulp is a leftover residue from starch production industry, which contains as high as 50- $60 \%$ starch content on dry basis [40], while the other main carbohydrates are cellulose and hemicelluloses [41]. To utilize the cellulose and hemicellulose in cassava pulp, it was acid hydrolysed and used as substrate for fermentative hydrogen production by anaerobic mixed cultures by Phowan and Danvirutai [42]. The optimal conditions for hydrolysis found were $0.5 \%$ $\mathrm{H}_{2} \mathrm{SO}_{4}$ at the ratio of 1:15 (dry wt.: volume) for $30 \mathrm{~min}$ and yielded $27.4 \mathrm{~g} / \mathrm{L}$ of total sugar. The experiments were carried out to determine the optimal operating conditions for hydrogen production. The results indicated that the Up-flow Anaerobic Sludge Blanket (UASB) granules yielded the highest hydrogen production at the initial total sugar concentration of $25 \mathrm{~g} \mathrm{COD} / \mathrm{L}$ with the biomass concentration of $3.0 \mathrm{~g} / \mathrm{L}$ and the initial medium $\mathrm{pH}$ of 5.5. The highest hydrogen yield of $342 \mathrm{ml} \mathrm{H}_{2} / \mathrm{g} \mathrm{COD}_{\text {reduced }}$ and the hydrogen production rate of $3381 \mathrm{ml} \mathrm{H}_{2} / \mathrm{L} / \mathrm{d}$ was obtained. The study demonstrates the possibility of using cassava pulp acid hydrolysate as the substrate for hydrogen production by the selected mixed culture. Cheng et. al. [43] used mixed bacteria in a two-step process to improve $\mathrm{H}_{2}$ yield from cassava starch. In darkfermentation, the mixed $\mathrm{H}_{2}$ producing culture (having more Clostridium sp.), was used in batch mode. Substrate concentration, fermentation temperature and $\mathrm{pH}$ were optimized as $10.4 \mathrm{~g} / \mathrm{L}$, $31{ }^{\circ} \mathrm{C}$ and 6.3 by response surface methodology (RSM). The maximum hydrogen yield and production rate in dark fermentation were $351 \mathrm{ml} \mathrm{H}_{2} / \mathrm{g}$ starch ( $2.53 \mathrm{~mol} \mathrm{H}_{2} / \mathrm{mol}$ hexose) and $334.8 \mathrm{ml}$ $\mathrm{H}_{2} / \mathrm{L} / \mathrm{h}$, respectively. For photo- fermentation, mixed immobilized photosynthetic bacteria (mainly $R$. palustris) were used. The maximum hydrogen yield in photo fermentation was $489 \mathrm{ml} \mathrm{H}_{2} / \mathrm{g}$ starch (3.54 mol $\mathrm{H}_{2} / \mathrm{mol}$ hexose). The total hydrogen yield was significantly increased from 402 to $840 \mathrm{ml} \mathrm{H}_{2} / \mathrm{g}$ starch (from 2.91 to $6.07 \mathrm{~mol} \mathrm{H}_{2} / \mathrm{mol}$ hexose) by mixed bacteria and cell immobilization in combination of dark and photo fermentation. Rai et. al. [44] used acid hydrolysed sugarcane bagasse (SCB) as substrate for biohydrogen production by integrating dark- and photo- fermentation. The SCB was hydrolysed by sulphuric acid and detoxified to remove the inhibitory furfural, and subjected to dark-fermentation by Enterobacter aerogenes MTCC 2822. Photofermentation of the spent medium was done by Rhodopseudomonas BHU 01. The acid hydrolysis residue was hydrolysed by Cellulomonas fimi to release sugars for $\mathrm{H}_{2}$ production by E. aerogenes, through simultaneous saccharification, filtration and fermentation (SSFF). Cumulative $\mathrm{H}_{2}$ production during dark-fermentation and SSFF was 1000 and $613 \mathrm{ml} / \mathrm{L}$, respectively. During photo-fermentation of spent media of dark-fermentation and SSFF by Rhodopseudomonas BHU 01 the cumulative $\mathrm{H}_{2}$ production was $755 \mathrm{ml} / \mathrm{L}$ and $351 \mathrm{ml} / \mathrm{L}$, respectively. Kumar et. al. [45] used hydrochloric acid- pre-treated hydrolysate of de-oiled jatropha waste (DJW) as substrate for biohydrogen production in batch mode. The optimal hydrolysate concentration, temperature and $\mathrm{pH}$ were found as $10.2 \mathrm{~g}$ reducing sugar $(\mathrm{RS}) / \mathrm{L}, 37{ }^{\circ} \mathrm{C}$ and 5.0 , respectively. The optimum values were used subsequently to run CSTR (continuously stirred tank reactor) at various hydraulic retention times (HRTs). Maximum hydrogen production rates (HPR) were reported to be $0.86 \mathrm{~L} \mathrm{H}_{2}$ $/ \mathrm{L} / \mathrm{d}$ and $0.15 \mathrm{~L} \mathrm{H}_{2} / \mathrm{L} / \mathrm{d}$ from batch and CSTR operations, respectively. Hydrochloric acid pre-treatment enlarged the pore size of the unhydrolyzed biomass (UHB) from 0.6 to $3.9 \mathrm{~mm}^{3} / \mathrm{g}$. Kumar et. al. [46] reported hydrogen production from cello-lignin fraction of de-oiled jatropha waste (DJW) as substrate for biohydrogen production using hybrid immobilized cells. The cellolignin fraction used was the non-hydrolyzed residue of acid pretreated DJW. For releasing the reducing sugars from non hydrolyzed fraction, enzyme pre-treatment was given. Hydrogen production was seen in a CSTR at various HRTs. Results showed a peak HPR of $3.65 \mathrm{~L} \mathrm{H}_{2} / \mathrm{L} / \mathrm{d}$ and $\mathrm{HY}$ of $150 \mathrm{~mL} \mathrm{H}_{2} / \mathrm{g}$ reducing sugars at the optimum HRT of $12 \mathrm{~h}$ and $37{ }^{\circ} \mathrm{C}$. Use of energy crops as feedstock for energy production has been studied for long time. But the use of energy crops as substrate for biohydrogen production can only be justified if the production cost of crops is low, has high biomass and is rich in fermentable sugars. However, the food vs. fuel debate laid down the use of energy crops as source of energy as there is a competition for land between food and energy crops.

\subsection{Algal biomass}

Use of algal biomass as substrate for biohydrogen production seems the most promising step towards sustainable energy generation. Algal spp. have relative high photosynthetic efficiencies, high growth rates, and can thrive in various water sources ranging from brackish water to wastewater from food- and agro-industrial sector. Algal biomass can be utilized by $\mathrm{H}_{2}$ producing microorganisms similar to other organic wastes as it is 
rich in carbohydrates, proteins and lipids (Table 4). It has added advantage that it can fix $\mathrm{CO}_{2}$ and unlike energy crops, it does not create 'land for food or for energy issue'. The complex carbohydrates present in algal biomass, are bound with rigid algal cell walls [47-48]. For utilization of these carbohydrates for fermentation, it is necessary to break the algal cell wall along with complex carbohydrate to facilitate the release of simple sugar [49]. For breaking the cell wall of algae and hydrolyzing the complex carbohydrates, several pre-treatments are employed such as physical (sonication, milling, grinding), chemical (acid, alkali) and biological methods (enzymatic). Each and every pre- treatment method has its own merits and demerits. Physical methods are simple but energy intensive, biological ones are costly and time consuming, so chemical methods are preferred over others because of higher conversion efficiency of complex carbohydrates into simpler fermentable sugars in lesser time [48, 50]. Pre- treatment increases the production cost of biohydrogen thus affects the overall economics of biohydrogen production from algal biomass. Kawaguchi et. al. [47] used marine green alga Dunaliella tertiolecta and the fresh water green alga Chlamydomonas reinhardtii biomass for biohydrogen production by a mixed culture of Lactobaccilus amylovorus and Rhodobium marinum A-501. L. amylovorus utilized algal starch for lactic acid production and $R$. marinum A-501 produced hydrogen in the presence of light using lactic acid as an electron donor. The yields of hydrogen obtained from starch contained in D. tertiolecta and $C$. reinhardtii were $61 \%$ and $52 \%$, respectively, in the mixed cultures of $L$. amylovorus and R. marinum A-501. Nguyen et. al. [51] utilized the accumulated starch in the green algae $C$. reinhardtii as substrate for $\mathrm{H}_{2}$ production by the hyperthermophilic eubacterium Thermotoga neapolitana. The bacterium having amylase activity could directly ferment the algal starch into $\mathrm{H}_{2}$ to the extent of 1.8$2.2 \mathrm{~mol} \mathrm{H}_{2} / \mathrm{mol}$ glucose. To enhance the hydrogen production two pre-treatment methods using the heat- $\mathrm{HCl}$ treatment and enzymatic hydrolysis were applied on algal biomass before using it as substrate for $\mathrm{H}_{2}$ production. The use of starch pre-treated by $1.5 \% \mathrm{HCl}$ at $121^{\circ} \mathrm{C}$ for 20 min resulted in $\mathrm{H}_{2}$ yield of $58 \%(\mathrm{v} / \mathrm{v})$ whereas the enzymatic digestion of starch by thermostable alpha amylase applied in the SHF process significantly enhanced $\mathrm{H}_{2}$ productivity of the bacterium to $64 \%$ (v/v) of total accumulated $\mathrm{H}_{2}$ level and a hydrogen yield of $2.5 \mathrm{~mol} \mathrm{H}_{2} / \mathrm{mol}$ glucose. Results demonstrated that direct $\mathrm{H}_{2}$ production from algal biomass was more cost effective as only one bacterial cultivation step was required for $\mathrm{H}_{2}$ production. Park et. al. [52] investigated the feasibility of hydrogen production from red algae biomass. Galactose, the main sugar of red algae, was successfully utilized for $\mathrm{H}_{2}$ production. The maximum $\mathrm{H}_{2}$ production rate and yield from galactose were $2.46 \mathrm{~L} \mathrm{H}_{2} / \mathrm{gVSS} / \mathrm{d}$ and $2.03 \mathrm{~mol} \mathrm{H}_{2} / \mathrm{mol}$ galactose $_{\text {added }}$ respectively, which were higher than those for glucose $\left(0.914 \mathrm{~L} \mathrm{H}_{2} / \mathrm{gVSS} / \mathrm{d}\right.$ and $1.48 \mathrm{H}_{2} / \mathrm{mol}$ galactose $\left.\mathrm{added}\right)$. The main byproduct of acid hydrolysis, 5- hydroxyl methyl furfural (HMF) caused inhibition in $\mathrm{H}_{2}$ fermentation and decreased $\mathrm{H}_{2}$ production rate by $50 \%$ compared to the control. But when red algae biomass was hydrolyzed at $150{ }^{\circ} \mathrm{C}(15 \mathrm{~min})$ and detoxified by activated carbon, $53.5 \mathrm{ml}$ of hydrogen was produced from $1 \mathrm{~g}$ of dry algae with a hydrogen production rate of $0.518 \mathrm{~L}$ $\mathrm{H}_{2} / \mathrm{gVSS} / \mathrm{d}$. They suggested that red algae could be the suitable substrate for $\mathrm{H}_{2}$ production. Jung et. al. [53] tested marine algae for their use as a substrate in fermentative $\mathrm{H}_{2}$ production by seed sludge microflora obtained from an aerobic digester in a local wastewater treatment plant. Among the algae tested, Laminaria japonica exhibited highest $\mathrm{H}_{2}$ yield of $69.1 \mathrm{ml} \mathrm{H}_{2} / \mathrm{g}$ COD added, and this was attributed to its high carbohydrate content and main constituent of alpha polysaccharides laminarine and alginates. To enhance $\mathrm{H}_{2}$ production from algal biomass, thermal pre-treatment was applied under various conditions. At $170{ }^{\circ} \mathrm{C}(20 \mathrm{~min}), \mathrm{H}_{2}$ yield was maximum (109.6 $\left.\mathrm{ml} \mathrm{H}_{2} / \mathrm{g} \mathrm{COD}_{\text {added }}\right)$. Jung et. al. [54] applied a combined (acid + thermal) pre-treatment for enhanced fermentative $\mathrm{H}_{2}$ production from L. japonica. Various pretreatment conditions including $\mathrm{HCl}$ concentrations, heating temperatures and reaction times were optimized via response surface methodology (RSM) with a Box-Behnken design (BBD). The desirable pretreatment conditions found were $\mathrm{HCl}$ concentrations $4.8 \%$, temp $93^{\circ} \mathrm{C}$ and reaction time 23 min, under which $\mathrm{H}_{2}$ yield reached $159.6 \mathrm{~mL} \mathrm{H}_{2} / \mathrm{g}$ dry cell weight. The main organic acids produced were acetic and butyric acid. The HMF, a byproduct formed

Table 4: Algal biomass used as substrate for biohydrogen production.

\begin{tabular}{|c|c|c|c|c|}
\hline S. No. & Biomass & Inoculum & Highest $\mathrm{H}_{2}$ yield & Reference \\
\hline 1. & Chlamydomonas reinhardtii & Thermotoga neapolitana & $311.1 \mathrm{~mL} \mathrm{H}_{2} / \mathrm{g}$ monosaccharides & [51] \\
\hline 2. & Laminaria japonica & Anaerobic mixed culture & $71.4 \mathrm{~mL} \mathrm{H}_{2} / \mathrm{g}$ dry biomass & [79] \\
\hline 3. & Microalgae & Enriched functional consortia & $25.1 \mathrm{~mL} \mathrm{H}_{2} / \mathrm{g}$ dry biomass powder & [80] \\
\hline 4. & Chlorella vulgaris & Heat pretreated anaerobic digestion sludge & $33.8 \mathrm{~mL} \mathrm{H}_{2} / \mathrm{g} \mathrm{VS}$ & [81] \\
\hline 5. & Anabaena spp. & Enterobacter aerogenes & $15.1 \mathrm{~mL} \mathrm{H}_{2} / \mathrm{g} \mathrm{VS}$ & [82] \\
\hline 6. & Arthrospira platensis & Heat pretreated anaerobic digestion sludge & $101.7 \mathrm{~mL} \mathrm{H}_{2} / \mathrm{g} \mathrm{VS}$ & [83] \\
\hline 7. & Gelidium amansii & Heat pretreated anaerobic digestion sludge & $44.6 \mathrm{~mL} \mathrm{H}_{2} / \mathrm{g} \mathrm{VS}$ & [56] \\
\hline 8. & Nannochloropsis oceanica & Heat pretreated anaerobic digestion sludge & $39.9 \mathrm{~mL} \mathrm{H}_{2} / \mathrm{g} \mathrm{VS}$ & [84] \\
\hline 9. & Laminaria japonica & Anaerobic digester sludge & $61.3 \mathrm{~mL} \mathrm{H}_{2} / \mathrm{g}$ dry biomass & [85] \\
\hline 10 & Chlorella sorokiniana & Enterobacter cloacae & $201.6 \mathrm{~mL} \mathrm{H}_{2} / \mathrm{g} \mathrm{COD}$ & [46] \\
\hline 11. & Untreated de-oiled algae cake & Anaerobic digester sludge & $66 \mathrm{~mL} \mathrm{H}_{2} / \mathrm{g}$ algal mass & [59] \\
\hline 12. & Scenedesmus obliquus & Enterobacter aerogenes & $57.6 \mathrm{~mL} \mathrm{H}_{2} / \mathrm{g} \mathrm{VS}$ & [86] \\
\hline 13. & Scenedesmus obliquus & Clostridium butyricum & $113.1 \mathrm{~mL} \mathrm{H}_{2} / \mathrm{g} \mathrm{VS}$ & [86] \\
\hline
\end{tabular}


during the pre-treatment process, showed an inverse relationship with $\mathrm{H}_{2}$ yield, indicating that pre-treatment conditions for $\mathrm{H}_{2}$ production from $L$. japonica were successfully optimized by increasing the hydrolysis rate of the feedstock and also reducing the formation of HMF. Liu et. al. [55] utilized carbohydrate-rich microalgal biomass of Chlorella vulgaris ESP6 for biohydrogen production. Algal biomass was hydrolyzed by acid or alkaline/enzymatic treatment, and was then used as substrate for biohydrogen production by $C$. butyricum CGS5. The biomass of $C$. vulgaris ESP6 was efficiently hydrolyzed by acid treatment with $1.5 \% \mathrm{HCl}$, giving a reducing sugars (RS) yield of nearly $100 \%$. The optimal conditions for hydrogen production were $37{ }^{\circ} \mathrm{C}$ and the microalgal hydrolysate loading of $9 \mathrm{~g} \mathrm{RS} / \mathrm{L}$ with $\mathrm{pH}$-controlled at 5.5. Under optimal conditions, cumulative $\mathrm{H}_{2}$ production, production rate, and yield were $1476 \mathrm{ml} / \mathrm{L}, 246 \mathrm{ml} / \mathrm{L} / \mathrm{h}$, and 1.15 $\mathrm{mol} / \mathrm{mol} \mathrm{RS}$, respectively. The results demonstrated that the $C$. vulgaris biomass has the potential to serve as effective feedstock for dark fermentative $\mathrm{H}_{2}$ production. Kumar et. al. [48] investigated biohydrogen production from algal biomass of Chlorella sorokiniana as substrate by Enterobacter cloacae IITBT-08. The pre-treated algal biomass (10 g/L) with $2 \%(\mathrm{v} / \mathrm{v}) \mathrm{HCl}-$ Heat was found most suitable for hydrogen production yielding $9 \pm 2 \mathrm{~mol} \mathrm{H}_{2} / \mathrm{kg} \mathrm{COD}$ reduced, and was fitting with Gompertz equation. The use of green algae as substrate for $\mathrm{H}_{2}$ production also helps in $\mathrm{CO}_{2}$ sequestration from the environment as green algae have the capacity to absorb $\mathrm{CO}_{2}$ from flue gas and eliminate the impact of global warming due to increasing concentration of $\mathrm{CO}_{2}$ in the atmosphere. Park et. el. [56] used marine algal biomass of Gelidium amansii and powdered $G$. amansii was hydrolyzed at (120-180 ${ }^{\circ} \mathrm{C}$ ), solid/liquid (S/L) ratio of 5-15\% (w/v), and $\mathrm{H}_{2} \mathrm{SO}_{4}$ conc of $0.5-1.5 \%(\mathrm{w} / \mathrm{w})$, and then fed to batch hydrogen fermentation using seed sludge obtained from anaerobic digestion in the local wastewater treatment plant. The maximum hydrogen production of $0.51 \mathrm{~L} \mathrm{H}_{2} / \mathrm{L} / \mathrm{h}$ and $37.0 \mathrm{~mL} \mathrm{H}_{2} / \mathrm{g}$ dry biomass was found at $161-164^{\circ} \mathrm{C}$ hydrolysis temp, $12.7-14.1 \% \mathrm{~S} / \mathrm{L}$ ratio and $0.50 \% \mathrm{H}_{2} \mathrm{SO}_{4}$. Roy et. al. [49] used C. sorokiniana pre-treated algal biomass as substrate for thermophilic biohydrogen production using mixed culture. The $C$. sorokiniana was cultivated in helical airlift photobioreactor and the resulting biomass was subjected to various physical and chemical pre-treatments. It was observed that pre-treatment with $200 \mathrm{dm}^{3} / \mathrm{m}^{3} \mathrm{HCl}$ heat was the most suitable pre-treatment resulting in cumulative $\mathrm{H}_{2}$ of 1.93 $\mathrm{m}^{3} / \mathrm{m}^{3}$ and $\mathrm{H}_{2}$ yield of $958 \mathrm{dm}^{3} / \mathrm{kg}$ volatile suspended solid or 2.68 $\mathrm{mol} / \mathrm{mol}$ of hexose. Liu and Wang [57] reported hydrogen production from algal biomass of L. japonica by anaerobic mixed bacteria. They investigated saccharification efficiency and hydrogen production by L. japonica with four different pretreatment methods, including heat, acid, alkaline and ultrasonic treatment. The results showed that saccharification efficiency from L. japonica pre-treated with acid was the highest among the four methods. The maximum hydrogen production $(83.45 \pm 6.96 \mathrm{~mL} / \mathrm{g})$ was achieved with $L$. japonica pre-treated with heat and an initial $\mathrm{pH}$ and substrate concentration of 6.0 and $2 \%$, respectively. They suggested that the marine macro-alga L. Japonica could be a utilized as a substrate for fermentative hydrogen production. Nayak et. al. [58] utilized Anabaena PCC 7120 biomass as substrate for biohydrogen production by thermophilic dark fermentative hydrogen production using mixed microflora. Maximum $\mathrm{H}_{2}$ production was found to be $1600 \mathrm{~mL} / \mathrm{L}$ upon pretreatment with amylase followed by thermophilic fermentation (24 h) compared to other methods like sonication $(200 \mathrm{~mL} / \mathrm{L})$, autoclave $(600 \mathrm{~mL} / \mathrm{L})$ and $\mathrm{HCl}$ treatment $(1230 \mathrm{~mL} / \mathrm{L})$. Amylase pre-treatment yielded higher reducible sugar content $(7.6 \mathrm{~g} / \mathrm{L})$ as compare to other pre-treatments. Thermophilic fermentation of pre-treated Anabaena biomass by mixed bacterial culture was found suitable for $\mathrm{H}_{2}$ production. Subhash and Venkata Mohan [59] applied an integrated biorefinery approach and used deoiled algal cake (after lipid extraction) as feed-stock for biohydrogen production using selectively enriched acidogenic consortia. Algae pre-treated extract (AP-E) documented maximum $\mathrm{H}_{2}$ production rate (HPR), cumulative $\mathrm{H}_{2}$ production (CHP) and specific $\mathrm{H}_{2}$ yield (SHY) with higher substrate degradation $(65 \%)$ in terms of COD removal efficiency than other conditions. The study signified the feasibility of microalgae as potential feedstock for simultaneous production of two energy forms viz., biodiesel and biohydrogen in the framework of biorefinery approach.

\section{CONCLUSION}

Fermentative hydrogen production from waste materials is considered as eco-friendly and promising route for hydrogen production. Fermentative bacteria can utilize a wide range of waste material as feedstock for $\mathrm{H}_{2}$ production. The exploitation of waste materials for $\mathrm{H}_{2}$ production not only leads to energy generation but also helps in bioremediation and in lowering the $\mathrm{H}_{2}$ production cost, thus making the process economically viable. The major obstacle in $\mathrm{H}_{2}$ production from waste material is the effective pretreatment method of substrate, low $\mathrm{H}_{2}$ rate and yield. To overcome the above obstacles, a lot of efforts and technical breakthroughs are required. A large variety of biomass and waters having different composition and origin have been tested as the potential substrate leading in many cases to very promising results. The food waste having high loading of carbohydrates have great potential for its use as substrate for biohydrogen production followed by most abundant and easily available lignocellulosic waste. Algal biomass has also shown good potential but production rate/yield is comparatively low. For efficient utilization of these materials, there is an urgent need to identify the effective, economically viable and nature- friendly methods for the hydrolysis/liberation of fermentable carbohydrates.

\section{Financial support and sponsorship: Nil.}

Conflict of Interests: There are no conflicts of interest.

\section{REFERENCES}

1. Das D, Veziroglu TN. Hydrogen production by biological processes: a survey of literature. Int J Hydrogen Energy. 2001; 26: 13-28.

2. Kapdan IK, Kargi F. Bio-hydrogen production from waste materials. Enzy Microbial Technol. 2006; 38: 569-582. 
3. Rai PK, Singh SP. Biological production of clean energy: Hydrogen. In: Recent Advances in Microbiology S. P. Tiwari, Rajesh Sharma and Rajeeva Gaur, Editors. Nova Science Publishers Inc. New York, USA; 2013 p. 55-84.

4. Venkata Mohan S. Harnessing of biohydrogen from wastewater treatment using mixed fermentative consortia: process evaluation towards optimization. Int J Hydrogen Energy. 2009; 34: 7460-7474.

5. Wang $Y$, Wang $H$, Feng $X$, Wang $X$, Huang J. Biohydrogen production from cornstalk wastes by anaerobic fermentation with activated sludge. Int J Hydrogen Energy. 2010; 35: 3092-3099.

6. Fang HHP., Li Chenlin, Zhang Tong. Acidophilic biohydrogen production from rice slurry. Int J Hydrogen Energy. 2006;31:683-692,

7. Seifert K, Waligorska M, Laniecki $M$. Hydrogen generation in photobiological process from dairy waste water. Int $\mathbf{J}$ Hydrogen Energy. 2010; 35: 9624-9629.

8. Eroglu E, Gunduz U, Yucel M, Turker L, Eroglu I. Photobiological hydrogen production from olive mill wastewater as sole substrate sources. Int J Hydrogen Energy. 2004; 29: 163-171.

9. Rai PK, Singh SP, Asthana RK. Biohydrogen Production from cheese whey wastewater in a two-step anaerobic process. Appl Biochem Biotechnol. 2012; 167: 1540-1549.

10. Melis A, Zhang L, Forestier M, Ghirardi ML, Seifert M. Sustained photobiological hydrogen gas production upon reversible inactivation of oxygen evolution in the green alga Chlamydomonas reinhardtii. Plant Physiol. 2000; 122:127-133.

11. Hallenbeck PC, Ghosh D. Advances in fermentative biohydrogen production: the way forward. Trends Biotechnol. 2009; 27: 287-297.

12. Rai PK. Hydrogen production from dairy and agro wastes by integrating dark- and photo- fermentation. Ph.D thesis, Banaras Hindu University, Varanasi-22005, India. 2013.

13. Kim MS, Lee TJ, Yoon YS, Lee IG, Moon KW. Hydrogen production from food processing wastewater and sewage sludge by anaerobic dark fermentation combined with photofermentation. In: Miyake J, Matsunaga T, Pietro AS, editors. Biohydrogen II. Amsterdam: Elsevier 2001; p. 263-272

14. Cappelletti BM, Reginatto V, Amante ER, Antônio RV. Fermentative production of hydrogen from cassava processing wastewater by Clostridium acetobutylicum. Ren Energy. 2011; 36:3367-3372.

15. Rai PK, Singh SP, Asthana RK. Dairy waste based fermentative $\mathrm{H}_{2}$ production. J Microbial World. 2011; 13: 207-213.

16. Rai PK, Singh SP, Asthana RK. Prospects of utilizing dairy waste for biohydrogen production. Int J Biotechnol Biosci. 2011; 1: 263-270.

17. Rai PK, Asthana RK, Singh SP. Optimization of photo- hydrogen production based on cheese whey spent medium. Int $\mathrm{J}$ Hydrogen Energy. 2014; 39: 7597-7603.

18. Xiao ND, Chen YG, Chen AH, Feng LY. Enhanced biohydrogen production from protein wastewater by altering protein structure and amino acids acidification type. Scientific Reports. 2014: 4, 3992; DOI: 10.1038/srep03992.

19. Jayalakshmi J, Joseph K, Sukumaran V. Bio hydrogen generation from kitchen waste in an inclined plug flow reactor. Int J Hydrogen Energy. 2009; 34:8854-8858.

20. Hwang JH, Choi JA, Abou-Shanab RAI, Min B, Song H, Kim Y, Lee ES, Jeon BH. Feasibility of hydrogen production from ripened fruits by a combined two-stage (dark/dark) fermentation system. Bioresour Technol. 2011; 102: 1051-1058.

21. Elbeshbishy E, Hafez H, Nakhla G. Ultrasonication for biohydrogen production from food waste. Int J Hydrogen Energy. 2011; 36: 2896-2903.

22. Zhang R, El Mashad HM, Hartman K, Wang F, Liu G, Choate C, Gamble P. Characterization of food waste as feedstock for anaerobic digestion. Bioresourc Technol. 2007; 98: 929-939.

23. Lee DY, Ebie Y, Xu KQ, Li YY, Inamori Y. Continuous $\mathrm{H}_{2}$ and $\mathrm{CH}_{4}$ production from high-solid food waste in the two-stage thermophilic fermentation process with the recirculation of digester sludge. Bioresourc Technol. 2010; 101: 542-547.

24. Kim DH, Kim SH, Shin HS. Hydrogen fermentation of food waste without inoculums addition. Enzyme Microb Technol. 2009; 45:181-87.
25. Kim SH, Shin HS. Effects of base- pretreatment on continuous enriched culture for hydrogen production from food waste. Int $\mathbf{J}$ Hydrogen Energy. 2008; 33:5266-5274.

26. Han SK, Shin HS. Biohydrogen production by anaerobic fermentation of food waste. Int J Hydrogen Energy. 2004; 29: 569-577.

27. Vijayaraghavan K, Ahmad D, Ibrahim MK. Biohydrogen generation from jackfruit peel using anaerobic contact filter. Int $\mathrm{J}$ Hydrogen Energy. 2006; 31:569-579.

28. Yasin HMN, Noraini AR, Hasfalina CM, Yusoff MZM, Hassan MA. Microbial characterization of hydrogen-producing bacteria in fermented food waste at different $\mathrm{pH}$ values. Int J Hydrogen Energy. 2011; 36: 9571-9580.

29. Danko AS, Pinheiro F, Abreu AA, Alves MM. Effect of methanogenic inhibitors, inocula type, and temperature on biohydrogen production from food components. Environ Eng Manage J. 2008; 7:531-536.

30. Elbeshbishy E, Hafez H, Dhar BR, Nakhla G. Single and combined effect of various pretreatment methods for biohydrogen production from food waste. Int J Hydrogen Energy. 2011; 36: 11379-11387.

31. Shin HS, Youn JH, Kim SH. Hydrogen production from food waste in anaerobic mesophilic and thermophilic acidogenesis. Int $\mathrm{J}$ Hydrogen Energy. 2004; 29:1355-1363.

32. Chu CF, Li YY, Xu KQ, Ebie Y, Inamori Y, Kong HN. A pH- and temperature-phased two-stage process for hydrogen and methane production from food waste. Int J Hydrogen Energy. 2008;33:4739-46.

33. Kim DH, Kim SH, Jung KW, Kim MS, Shin HS. Effect of initial pH independent of operational $\mathrm{pH}$ on hydrogen fermentation of food waste. Bioresour Technol. 2011; 102:8646-8652.

34. Venkata Mohan, Mohanakrishna G, Goud RK, Sarma PN. Acidogenic fermentation of vegetable based market waste to harness biohydrogen with simultaneous stabilization. Bioresourc Technol. 2009; 100: 3061 68

35. Kim DH, Kim SH, Kim KY, Shin HS. Experience of pilot-scale hydrogen producing anaerobic sequencing batch reactor (ASBR) treating food waste. Int J Hydrogen Energy. 2010; 35:1590-1594.

36. Reddy MV, Chandrasekhar K, Venkata Mohan S. Influence of carbohydrates and proteins concentration on fermentative hydrogen production using canteen based waste under acidophilic microenvironment. J Biotechnol. 2011; 155:387-395.

37. Kumar G, Bakonyi P, Periyasamy S, Kim SH, Nemestóthy N, BélafiBakó K. Lignocellulose biohydrogen: practical challenges and recent progress. Ren Sustain Energy Reviews. 2015; 44, 728-737.

38. Van Wyk JPH, Mohulatsi M. Biodegradation of wastepaper by cellulase from Trichoderma viride. Bioresour Technol. 2003; 86:2123.

39. Yang H, Guo L, Liu F. Enhanced bio-hydrogen production from corncob by a two-step process: dark- and photo-fermentation. Bioresour Technol. 2010; 101:2049-2052.

40. Sriroth K, Chollakup R, Chotineeranat S, Piyachomkwan K, Christopher GO. Processing of cassava waste for improved biomass utilization. Bioresour Technol. 2000; 71:63-69.

41. Manish S, Banerjee R. Comparison of biohydrogen production processes. Int J Hydrog Energy. 2008; 33:279-286.

42. Phowan P, Danvirutai P. Hydrogen production from cassava pulp hydrolysate by mixed seed cultures: Effects of initial $\mathrm{pH}$, substrate and biomass concentrations. Biomass Bioenergy. 2014; 64; 1-10.

43. Cheng J, Su H, Zhou J, Song W, Cen K. Hydrogen production by mixed bacteria through dark and photo fermentation. Int $\mathrm{J}$ Hydrogen Energy. 2011; 36: 450-457,

44. Rai PK, Singh SP, Asthana RK. Biohydrogen production from sugarcane bagasse by integrating dark- and photo-fermentation. Bioresour Technol. 2014; 152:140-146.

45. Kumar G, Sivagurunathan P, Chen Chin-Chao, Lin Chiu-Yue. Batch and continuous biogenic hydrogen fermentation of acid pretreated deoiled Jatropha waste (DJW) hydrolysate. RSC Adv. 2016; 6:45482-91.

46. Kumar G, Sen B, Sivagurunathan P, Lin Chiu-Yue. High rate hydrogen fermentation of cello-lignin fraction in de-oiled jatropha waste using hybrid immobilized cell system. Fuel 2016; 182:131-140. 
47. Kawaguchi $\mathrm{H}$, Hashimoto K, Hirata $\mathrm{K}$, Miyamoto $\mathrm{K}$. $\mathrm{H}_{2}$ production from algal biomass by a mixed culture of Rhodobium marinum A-501 and Lactobacillus amylovorus. J Biosci Bioeng. 2001; 91:277-282.

48. Kumar K, Roy S, Das D. Continuous mode of carbon dioxide sequestration by $C$. sorokiniana and subsequent use of its biomass for hydrogen production by E. cloacae IIT-BT 08.Bioresour Technol. 2013;145:116122.

49. Roy S, Kumar K, Ghosh S, Das D. Thermophilic biohydrogen production using pre- treated algal biomass as substrate. Biomass Bioenergy. 2014; 61:157-166.

50. Nguyen MT, Choi SP, Lee J, Lee JH, Sim SJ. Hydrothermal acid pretreatment of Chlamydomonas reinhardtii biomass for ethanol production. J Microbiol Biotechnol. 2009; 19:161-166.

51. Nguyen TAD, Kim KR, Nguyen MT, Kim MS, Kim D, Sim SJ. Enhancement of fermentative hydrogen production from green algal biomass of Thermotoga neapolitana by various pretreatment methods. Int $\mathrm{J}$ Hydrogen Energy. 2010; 35:13035-13040.

52. Park JH, Yoon JJ, Park HD, Kim YJ, Lim DJ, Kim SH. Feasibility of biohydrogen production from Gelidium amansii. Int J Hydrogen Energy. 2011; 36:13997-14003

53. Jung KW, Kim DH, Shin HS. Fermentative hydrogen production from Laminaria japonica and optimization of thermal pretreatment conditions. Bioresour Technol. 2011; 102:2745-2750.

54. Jung KW, Kim DH, Kim HW, Shin HS. Optimization of combined (acid + thermal) pretreatment for fermentative hydrogen production from Laminaria japonica using response surface methodology (RSM). Int J Hydrogen Energy. 2011; 36: 9626-9631.

55. Liu CH, Chang CY, Cheng CL, Lee DJ, Chang JS. Fermentative hydrogen production by Clostridium butyricum CGS5 using carbohydrate-rich microalgal biomass as feedstock. Int J Hydrogen Energy. 2012; 37: 15458 15464.

56. Park JH, Cheon HC, Yoon JJ, Park HD, Kim SH. Optimization of batch dilute-acid hydrolysis for biohydrogen production from red algal biomass. Int J Hydrogen Energy. 2013; 38: 6130-6136.

57. Liu H, Wang G. Fermentative hydrogen production from macroalgae Laminaria japonica using anaerobic mixed Bacteria. Int $\mathbf{J}$ Hydrogen Energy. 2014; 39: 9012-9017.

58. Nayak BK, Roy S, Das D. Biohydrogen production from algal biomass (Anabaena sp. PCC 7120) cultivated in airlift photobioreactor. Int J Hydrogen Energy. 2014; 39:7553-7560.

59. Subhash G and Venkata Mohan SV. Deoiled algal cake as feedstock for dark fermentative biohydrogen production: An integrated biorefinery approach. Int J Hydrogen Energy. 2014; 39: 9573-9579.

60. Ferchichi M, Crabbe E, Hintz W, Gill GH, Almadidy A. Influence of culture parameters on biological hydrogen production by Clostridium saccharoperbutylacetonium ATCC 27021. World J Microbiol Biotechnol. 2005; 21: 855-862.

61. Yang P, Zhang R, McGarvey JA, Benemann JR. Biohydrogen production from cheese processing wastewater by anaerobic fermentation using mixed microbial communities. Int J Hydrogen Energy. 2007; 32: 4761-4771.

62. Azbar N, Dokgöz FTC, Keskin T, Korkmaz KS, Syed HM. Continuous fermentative hydrogen production from cheese whey wastewater under thermophilic anaerobic conditions. Int J Hydrogen Energy. 2009; 34:7441 7447.

63. Oh SE, Logan BE. Hydrogen and electricity production from a food processing wastewater using fermentation and microbial fuel cell technologies. Water Res. 2005; 39: 4673-4682.

64. Davila-Vazquez G, Cota-Navarro CB, Rosales-Colunga LM, LeónRodríguez A, Razo- Flores E. Continuous biohydrogen production using cheese whey: improving the hydrogen production rate. Int J Hydrogen Energy. 2009; 34:4296-4304.

65. Amorim NCS, Alves I, Martins JS, Amorim ELC. Biohydrogen Production from Cassava Wastewater in an Anaerobic Fluidized Bed Reactor. Brazilian J Chem Eng. 2014; 31:603-612.

66. Han SK, Shin HS. Biohydrogen production by anaerobic fermentation of food waste. Int J Hydrogen Energy. 2004; 29:569-577.

67. Wang CH, Lin PJ, Chang JS. Fermentative conversion of sucrose and pineapple waste into hydrogen gas in phosphate-buffered culture seeded with municipal sewage sludge. Process Biochem. 2006; 41:1353-1358.

68. Doi T, Matsumoto H, Abe J, Morita S. Feasibility study on the application of rhizosphere microflora of rice for the biohydrogen production from wasted bread. Int J Hydrogen Energy. 2009; 34: 1735-1743.
69. Li SL, Lin JS, Wang YH, Lee ZK, Kuo SC, Tseng IC, Cheng SS. Strategy of controlling the volumetric loading rate to promote hydrogen-production performance in mesophilic-kitchen-waste fermentor and the microbial ecology analyses. Bioresourc Technol. 2011; 102:8682-8687.

70. Pattra S, Sangyoka S, Boonmee M, Reungsang A. Biohydrogen production from the fermentation of sugarcane bagasse hydrolysate by Clostridium butyricum. Int J Hydrogen Energy. 2008; 33:6058-6065.

71. Panagiotopoulos IA, Bakker RR, De Vrije T, Koukios EG, Classen PAM. Pretreatment of sweet sorghum bagasse for hydrogen production by Caldicellulosiruptor saccharolyticus. Int J Hydrogen Energy. 2010; 35:77387747 .

72. Wang Y, Wang H, Feng X, Wang X, Huang J. Biohydrogen production from cornstalk wastes by anaerobic fermentation with activated sludge. Int J Hydrogen Energy. 2010; 35:3092-3099.

73. Nasirian N, Almassi M, Minaei S, Widmann R. Development of a method for biohydrogen production from wheat straw by dark fermentation. Int $\mathrm{J}$ Hydrogen Energy. 2011; 36:411-420.

74. Cui M and Shen J. Effects of acid and alkaline pretreatments on the biohydrogen production from grass by anaerobic dark fermentation. Int $\mathrm{J}$ Hydrogen Energy. 2012; 37:1120-1124.

75. Han H, Wei L, Liu B, Yang H, Shen J. Optimization of biohydrogen production from soybean straw using anaerobic mixed bacteria. Int $\mathrm{J}$ Hydrogen Energy. 2012; 37:13200-13208.

76. Lay CH, Sen B, Chen CC, Wu JH, Lee SC, Lin CY. Co-fermentation of water hyacinth and beverage wastewater in powder and pellet form for hydrogen production. Bioresour Technol. 2013; 135:610-615.

77. Zhao L, Cao GL, Wang AJ, Guo WQ, Ren HY, Ren NQ. Simultaneous saccharification and fermentation of fungal pre-treated cornstalk for hydrogen production using Thermoanaerobacterium thermosaccharolyticum W16. Bioresour Technol. 2013; 145:103-107.

78. Song ZX, Li XH, Li WW, Bai YX, Fan YT, Hou HW. Direct bioconversion of raw corn stalk to hydrogen by a new strain Clostridium sp. FS3. Bioresour Technol. 2014; 157:91-97.

79. Shi X, Jung KW, Kim DH, Ahn YT, Shin HS. Direct fermentation of Laminaria japonica for biohydrogen production by anaerobic mixed cultures. Int J Hydrogen Energy. 2011; 36:5857-5864.

80. Ho KL, Lee DJ, Su A, Chang JS. Biohydrogen from lignocellulosic feedstock via one-step process. Int J Hydrogen Energy. 2012; 37: 1556974 .

81. Yun YM, Jung KW, Kim DH, Oh YK, Shin HS. Microalgal biomass as a feedstock for biohydrogen production. Int J Hydrogen Energy. 2012; 37:15533-15539.

82. Ferreira AF, Marques AC, Batista AP, PASS Marques, Gouveia L, Silva $\mathrm{CM}$. Biological hydrogen production by Anabaena sp - yield, energy and $\mathrm{CO}_{2}$ analysis including fermentative biomass recovery. Int $\mathrm{J}$ Hydrogen Energy. 2012; 37:179-190.

83. Cheng J, Xia A, Liu Y, Lin R, Zhou J, Cen K. Combination of dark- and photo-fermentation to improve hydrogen production from Arthrospira platensis wet biomass with ammonium removal by zeolite. Int J Hydrogen Energy. 2012; 37: 13330-13337.

84. Xia A, Cheng J, Lin R, Lu H, Zhou J, Cen K. Comparison in dark hydrogen fermentation followed by photo hydrogen fermentation and methanogenesis between protein and carbohydrate compositions in Nannochloropsis oceanica biomass. Bioresour Technol. 2013; 138:204213.

85. Shi X, Kim DH, Shin HS, Jung KW. Effect of temperature on continuous fermentative hydrogen production from Laminaria japonica by anaerobic mixed cultures. Bioresour Technol. 2013; 144:225-231.

86. Batista AP, Moura P, Marques PASS, Ortigueira J, Alves L, Gouveia L. Scenedesmus obliquus as feedstock for biohydrogen production by Enterobacter aerogenes and Clostridium butyricum. Fuel. 2014; 117:537543.

\section{How to cite this article:}

Rai PK. Recent Advances in substrate utilization for fermentative hydrogen Production. J App Biol Biotec. 2016; 4 (06): 059-067. DOI: $10.7324 / \mathrm{JABB} .2016 .40608$ 